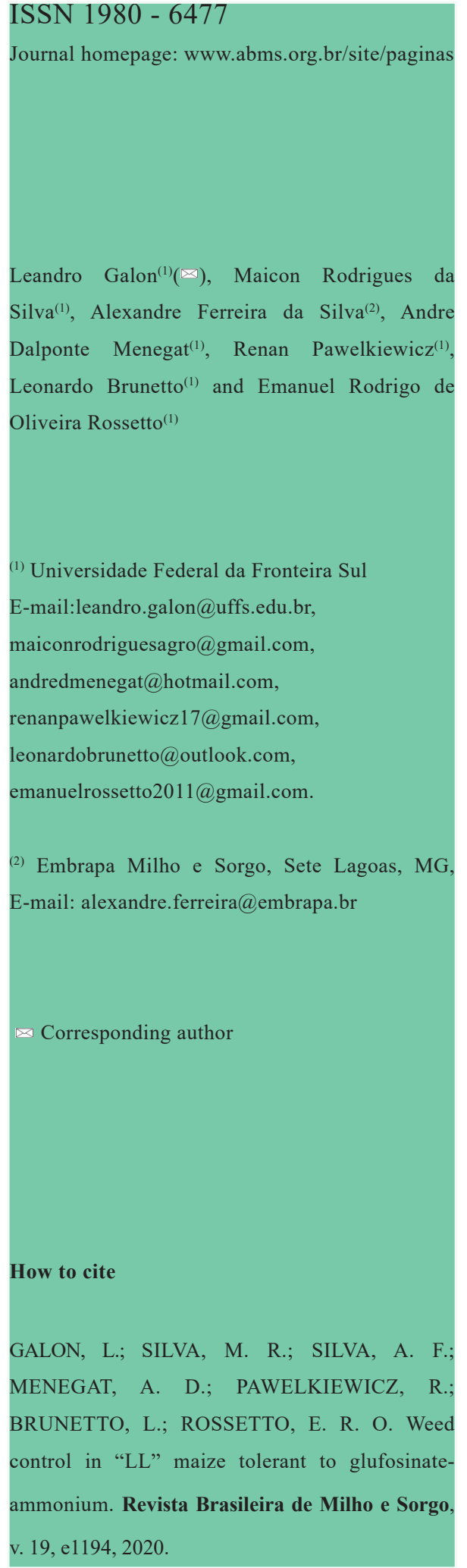

\section{WEED CONTROL IN "LL" MAIZE TOLERANT TO GLUFOSINATE-AMMONIUM}

\begin{abstract}
The glufosinate-ammonium is an herbicide with contact action and, when used in tolerant LL maize, requires associations with other products to improve the weed control spectrum and increase the residual period in the area. The aim of this work was to evaluate the efficacy and selectivity of glufosinate-ammonium, applied alone and in combination with other herbicides, for weed control in maize crops. The treatments consisted of two strategies. In the first one, the following herbicides were applied in pre-emergence conditions: atrazine, [atrazine + simazine], [atrazine + oil], [atrazine + S-metolachlor], and S-metolachlor; with the subsequent application of glufosinate-ammonium in post-emergence condition of maize. The second application method corresponded to the use of glufosinate-ammonium, alone and combined with nicosulfuron + mesotrione and the other products used in the first strategy, in addition to two control areas, being one weed-infested and the other weed-free. Phytotoxicity on maize and weed control were assessed. Ear insertion height, number of rows per ear, number of grains per row, thousand grain weight and maize yield were determined upon harvesting. The herbicides were effective and did not cause yield loss to the crop. The herbicides applied in combination with glufosinate-ammonium were efficient in regard to weed control and selective to maize.
\end{abstract}

Keywords: Helianthus annuus, Raphanus sativus, Urochloa plantaginea, Zea mays.

\section{CONTROLE DE PLANTAS DANINHAS EM MILHO TOLERANTE AO AMÔNIO GLUFOSINATO "LL"}

Resumo - O amônio glufosinato é um herbicida com ação de contato e quando usado em milho tolerante "LL" necessita de associações com outros produtos para melhorar o espectro de controle e aumentar o período residual na área. Objetivou-se com o trabalho avaliar a eficácia e a seletividade de amônio glufosinato, aplicado de modo isolado e em associação com outros herbicidas para o controle de plantas daninhas em milho. Os tratamentos consistiram em duas estratégias, sendo a primeira usada em condições de pré-emergência os herbicidas: atrazina, [atrazina + simazina], [atrazina + óleo], [atrazina + s-metolacloro] e s-metolacloro, seguidos pela aplicação de amônio glufosinato na condição de pós-emergência do milho. A segunda modalidade de aplicação correspondeu ao uso de amônio glufosinato isolado e em associação com nicossulfurom + mesotriona e os demais produtos utilizados na alternativa anterior, além de duas testemunhas uma infestada e outra capinada. Foram avaliadas a fitotoxicidade sobre o milho e o controle das plantas daninhas. A altura de inserção de espiga, número de fileiras por espiga, número grãos por fileira, massa de mil grãos e produtividade do milho foram determinados na colheita. Os herbicidas foram eficazes e não ocasionaram perdas de rendimento à cultura. Os herbicidas aplicados em associação com o amônio glufosinato foram eficazes no controle das plantas daninhas e seletivos ao milho.

Palavras-chave: Helianthus annuиs, Raphanus sativus, Urochloa plantaginea, Zea mays. 
Maize stands out as one of the main crops cultivated in nearly the entire Brazilian territory, leading Brazil to hold the third position in the global production rating, after the United States and China. The grain production in the 2018/19 crop season in Brazil was estimated at approximately 100 million tonnes, occupying an area ofabout 17.5 million hectares, with an average productivity of $5,718 \mathrm{~kg} \mathrm{ha}^{-1}$ (Acompanhamento da Safra Brasileira [de] Grãos, 2020).

The inadequate management of weeds is one of the factors that may directly interfere with crop yield (Wandscheer et al., 2014). The lack of control may cause yield reductions of over $80 \%$ and even influence the quality of the harvested grain (Galon et al., 2018). Because of the high losses, it becomes necessary to perform the appropriate management of the weed community. Chemical control is the most applied method due to its efficacy, practicality and lower cost when compared to other control methods (Timossi \& Freitas, 2011). There are 40 active ingredients registered for use in pre- and postemergence of maize (Brasil, c2003). However, after the introduction of glyphosate-resistant hybrids (RR), there was a drastic reduction in the diversity regarding the use of molecules of different mechanisms of action. In maize crops, the weed management is mainly based on the use of glyphosate combined with atrazine (Silva et al., 2018).

The low cost of glyphosate, associated with its broad action spectrum, selectivity to RR crops and high control efficacy, contributed to the continuous application of that herbicide in the production systems, thus favoring the selection pressure for resistant biotypes within the weed populations (Westwood et al., 2018). In Brazil, there are nine weed species that are resistant to this herbicide molecule (Heap, 2020). Weed biotypes resistant and tolerant to glyphosate are widely distributed throughout the main grainproducing regions in Brazil (Lucio et al., 2019). Such fact has been causing an increase in weed control costs and yield losses, resulting in high losses to farmers (Adegas et al., 2017). In view of this scenario, the search for new control alternatives is required.

Maize tolerant to glufosinate-ammonium, with LibertyLink ${ }^{\circledR}$ technology (LL), represents the possibility of using a new alternative to help with weed management. This herbicide is characterized by contact action, being applied in post-emergence conditions, with broad action spectrum (Rodrigues \& Almeida, 2018). The glufosinate-ammonium inhibits the action of the glutamine synthetase (GS) enzyme, causing the accumulation of ammonia in the cells, which results in membrane disruption, inhibition of photosynthesis and, consequently, the death of plants (Latorre et al., 2013). As it is an herbicide of broad action spectrum, it is usually applied in presowing desiccation or used in directed spraying. Tolerant crops are responsible for converting the glufosinate-ammonium into non-toxic metabolites. Currently in the Brazilian market, there are soybean, maize and cotton cultivars that are tolerant to that herbicide molecule (Comissão 
Técnica Nacional de Biossegurança, 2020).

Management programs that involve crops tolerant to glufosinate-ammonium tend to use this active ingredient associated with other herbicide molecules (Adegas et al., 2017). This fact deserves attention, since the association of different products may cause antagonistic effects or physical and chemical incompatibilities, thus resulting in losses of efficacy and selectivity to the crop (Galon et al., 2018). Therefore, studies that assess the efficacy and selectivity of herbicide combinations are of great importance for the appropriate positioning of the technology in the market.

In this sense, the objective of this work was to assess the efficacy of the glufosinate -ammonium, alone and in combination with herbicides registered, in the maize crop, for control of radish (Raphanus sp.), alexandergrass (Urochloa plantaginea) and sunflower (Helianthus annuus), in addition to assessing the selectivity to the 2A521 PW hybrid.

\section{Material and Methods}

The experiment was conducted on the experimental area of the Federal University of Fronteira Sul (UFFS), Erechim Campus, from October 2018 to February 2019. Sowing was carried out on residues (straw) in no-tillage system. The area was previously cultivated with a winter cover crop consisting of black oat + radish. The desiccation of those plants was done with the application of glyphosate $\left(1440 \mathrm{~g} \mathrm{ha}^{-1}\right)$,
30 days before maize sowing, with dry mass production of $5.7 \mathrm{t} \mathrm{ha}^{-1}$. The soil was classified as typical aluminum-ferric Red Latosol (Santos et al., 2013). The experiment was installed in randomized block design, with four replications. The treatments are described in Table 1.

Fertility was corrected according to the soil chemical analysis, taking into account the recommendations for maize crop intended for grain production (Manual..., 2016). Fertilizer was applied in the sowing furrow, in the amount of $433 \mathrm{~kg} \mathrm{ha}^{-1}$ of the $05-30-15$ (N-P-K) formulation, in addition to urea application in the amount of $310 \mathrm{~kg} \mathrm{ha}^{-1}$, when the maize plant had, on average, six fully expanded leaves (V6).

Seeds of the single cross maize hybrid (Forseed 2A521 PW) were sown, with 0.50 $\mathrm{m}$ spacing between rows and density of 3.65 seeds per linear meter, providing a population of approximately 73,000 plants ha-1. The plots were composed of six rows with $5 \mathrm{~m}$ length x $3 \mathrm{~m}$ width, totaling and area of $15 \mathrm{~m}^{2}$. The useful plot area was $6 \mathrm{~m}^{2}(2 \times 3 \mathrm{~m})$. The weeds occurring in the experimental area were radish (Raphanus sp.), alexandergrass (Urochloa plantaginea) and sunflower (Helianthus annuиs), in average densities of 33, 193 and 12 plants $\mathrm{m}^{-2}$, respectively, emerged from the soil seed bank.

Herbicides were applied with the use of $\mathrm{CO}_{2}$ pressurized backpack sprayer, equipped with four flat-fan spray nozzles (DG110.02), keeping constant pressure of $210 \mathrm{kPa}$ and travel speed of $3.6 \mathrm{~km} \mathrm{~h}^{-1}$, which provided flow rate of $150 \mathrm{~L} \mathrm{ha}^{-1}$. On the same day of maize sowing and after that, 
Table 1. Treatments used in the experiment, the respective dose and period of application for weed control in the Forseed 2A521PW maize hybrid. UFFS, Erechim, RS.

\begin{tabular}{|c|c|c|c|c|}
\hline Treatments & $\begin{array}{l}\text { Doses } \\
\left(\mathrm{g} \mathrm{ha}^{-1}\right)\end{array}$ & Adjuvant & $\begin{array}{l}\text { Doses } \\
\% \mathrm{v} / \mathrm{V}\end{array}$ & $\begin{array}{c}\text { Type of } \\
\text { application }\end{array}$ \\
\hline 01-Weed-infested control area & $\ldots$ & $\ldots$ & $\ldots$ & $\ldots$ \\
\hline 02-Weed-free control area & $\cdots$ & $\ldots$ & $\ldots$ & $\ldots$ \\
\hline 03-Atrazine + glufosinate-ammonium & $2500+200$ & Hoefix & 0.2 & Pre/Post \\
\hline 04-[Atrazine + simazine] + glufosinate-ammonium & $1500+1500+200$ & Hoefix & 0.2 & Pre/Post \\
\hline $05-[$ Atrazine + oil $]+$ glufosinate-ammonium & $2400+200$ & Hoefix & 0.2 & Pre/Post \\
\hline 06-S-metolachlor + glufosinate-ammonium & $1680+200$ & Hoefix & 0.2 & Pre/Post \\
\hline 07-[Atrazine + S-metolachlor $]+$ glufosinate-ammonium & $1665+1215+200$ & Hoefix & 0.2 & Pre/Post \\
\hline 08-Glufosinate-ammonium & 200 & Hoefix & 0.2 & Post \\
\hline 09-Glufosinate-ammonium + atrazine & $200+2500$ & Hoefix & 0.2 & Post \\
\hline 10-Glufosinate-ammonium + [atrazine + oil $]$ & $200+2400$ & Hoefix & 0.2 & Post \\
\hline 11-Glufosinate-ammonium + S-metolachlor & $200+1680$ & Hoefix & 0.2 & Post \\
\hline 12-Glufosinate-ammonium + [atrazine + simazine $]$ & $200+1500+1500$ & Hoefix & 0.2 & Post \\
\hline 13-Glufosinate-ammonium + [atrazine + S-metolachlor $]$ & $200+1665+1215$ & Hoefix & 0.2 & Post \\
\hline 14-Glufosinate-ammonium $+[$ nicosulfuron + mesotrione $]$ & $200+23.4+109.4$ & Hoefix & 0.2 & Post \\
\hline
\end{tabular}

the herbicides were applied in pre-emergence conditions. When the maize plant had four fully expanded leaves (V4), the radish and sunflower had two to four leaves, and the marmeladegrass had four leaves to one tiller, the herbicides were applied in post-emergence conditions.

The assessment of phytotoxicity on the maize plants and the weed control were performed 7, 14 and 21 days after treatment application (DAT), using a rating scale from zero (0) to a hundred (100), where $0 \%$ corresponds to no plant injury or control treatment, and $100 \%$ corresponds to plant death or total control of weeds (Velini et al., 1995).

The variables assessed at pre-harvest of maize were: ear insertion height $(\mathrm{EIH})$, with measurement being made in ten plants, using a ruler, from the base up to the insertion point of the first ear; number of rows per ear (NRE) and number of grains per row (NGR), which were determined through random sampling in ten ears from each plot.

Maize was manually harvested when the grains reached 20\% moisture. Threshing of ears was done right after harvesting in a stationary plot thresher. The thousand grain weight (g) was determined by counting eight samples of 100 grains from each plot, with the crop yield being estimated subsequently, and the moisture content standardized at $13 \%$.

The data were submitted to normality and additivity tests. After error normality was 
confirmed, the analysis of variance was conducted through F-test and, when significant, Scott-Knott test $(\mathrm{p} \leq 0.05)$ was applied.

\section{Results and Discussions}

All analyzed variables presented significant effects in regard to the treatments. Low levels of phytotoxicity were observed in the maize crop from 7 to 14 DAT (Table 2). At 7 DAT, the treatment with glufosinate-ammonium caused no phytotoxicity symptoms on the crop when applied alone. At 14 DAT, all herbicides caused phytotoxicity, though the symptoms were always inferior to 5\%. At 21 DAT, the crop did no present any level of phytotoxicity caused by the herbicides. The selectivity of the glufosinate-ammonium, applied alone or in combination with other herbicides, has been assessed in other works (Armel et al., 2008; Burke et al., 2008; Silva et al., 2017). In general, the results indicate that the glufosinateammonium applied alone in LL maize produces no phytotoxicity symptoms. However, when used in association with other herbicides, there may be selectivity losses. Burke et al. (2008)

Table 2. Phytotoxicity (\%) on Forseed 2A521PW maize hybrid, as a function of applications of herbicides combined with glufosinate-ammonium. UFFS, Erechim, RS, 2018/19.

\begin{tabular}{lcccc}
\hline & \multirow{2}{*}{$\begin{array}{c}\text { Type of } \\
\text { Treatments }\end{array}$} & \multicolumn{2}{c}{ Phytotoxicity on maize (\%) } \\
\cline { 4 - 5 } & application & 07 DAT $^{1}$ & 14 DAT & 21 DAT \\
\hline 01-Weed-infested control area & --- & $0.00 \mathrm{~b}^{2}$ & $0.00 \mathrm{c}$ & $0.00^{\text {ns }}$ \\
02-Weed-free control area & -- & $0.00 \mathrm{~b}$ & $0.00 \mathrm{c}$ & 0.00 \\
03-Atrazine+glufosinate-ammonium & Pre/Post & $4.00 \mathrm{a}$ & $3.00 \mathrm{~b}$ & 0.00 \\
04-[Atrazine+simazine]+glufosinate-ammonium & Pre/Post & $4.00 \mathrm{a}$ & $3.50 \mathrm{~b}$ & 0.00 \\
05-[Atrazine+oil]+glufosinate-ammonium & Pre/Post & $3.50 \mathrm{a}$ & $3.50 \mathrm{~b}$ & 0.00 \\
06-S-metolachlor+glufosinate-ammonium & Pre/Post & $4.00 \mathrm{a}$ & $3.00 \mathrm{~b}$ & 0.00 \\
07-[Atrazine+S-metolachlor]+glufosinate-ammonium & Pre/Post & $3.50 \mathrm{a}$ & $4.00 \mathrm{a}$ & 0.00 \\
08-Glufosinate-ammonium & Post & $0.00 \mathrm{~b}$ & $3.00 \mathrm{~b}$ & 0.00 \\
09-Glufosinate-ammonium +atrazine & Post & $4.50 \mathrm{a}$ & $5.00 \mathrm{a}$ & 0.00 \\
10-Glufosinate-ammonium +[atrazine+oil] & Post & $3.00 \mathrm{a}$ & $5.00 \mathrm{a}$ & 0.00 \\
11-Glufosinate-ammonium +S-metolachlor & Post & $3.00 \mathrm{a}$ & $4.50 \mathrm{a}$ & 0.00 \\
12-Glufosinate-ammonium +[atrazine+simazine] & Post & $3.50 \mathrm{a}$ & $4.50 \mathrm{a}$ & 0.00 \\
13-Glufosinate-ammonium +[atrazine+S-metolachlor] & Post & $5.00 \mathrm{a}$ & $4.00 \mathrm{a}$ & 0.00 \\
14-Glufosinate-ammonium +[nicosulfuron+mesotrione] & Post & $3.00 \mathrm{a}$ & $5.00 \mathrm{a}$ & 0.00 \\
\hline CV (\%) & & 37.2 & 40.43 & 0.00 \\
\hline
\end{tabular}

${ }^{1}$ Days after treatment application. ${ }^{2}$ Means followed by the same letters in the column do not differ among one another as per Scott-Knott test at $\mathrm{p} \leq 0.05$. 
observed that the application of glufosinateammonium $\left(300 \mathrm{~g} \mathrm{ha}^{-1}\right)+$ mesotrione $(70 \mathrm{~g}$ ha $^{-1}$ ) in maize plant, 40 days after its emergence, resulted in phytotoxicity levels of up to $23 \%$, but the symptoms disappeared throughout the evaluation period and there were no yield losses. The herbicide selectivity to the crop may be influenced by the cultivar, plant development stage, doses applied, conditions of climate and soil (physical and chemical).

With regard to the control of alexandergrass, all herbicide treatments promoted control levels close to or above $90 \%$, at 7 and 14 DAT (Table 3). At 21 DAT, the best chemical control strategies consisted in the application, in post-emergence condition, of the glufosinateammonium combined with atrazine and also with the formulated mixtures of [atrazine+simazine] and [atrazine + S-metolachlor]. The greaterefficacy of these treatments may be related to the postemergence control provided by the glufosinateammonium associated with the residual effect

Table 3. Control (\%) of alexandergrass - Urochloa plantaginea, infesting the maize hybrid (Forseed 2A521PW) crop, as a function of applications of herbicides combined with glufosinate-ammonium. UFFS, Erechim, RS, 2018/19.

\begin{tabular}{|c|c|c|c|c|}
\hline \multirow{2}{*}{ Treatments } & \multirow{2}{*}{$\begin{array}{c}\text { Type of } \\
\text { application }\end{array}$} & \multicolumn{3}{|c|}{ Control of alexandergrass $(\%)$} \\
\hline & & $7 \mathrm{DAT}^{1}$ & 14 DAT & $21 \mathrm{DAT}$ \\
\hline 01-Weed-infested control area & --- & $0 \mathrm{~d}^{2}$ & $0 \mathrm{c}$ & $0 \mathrm{e}$ \\
\hline 02-Weed-free control area & --- & $100 \mathrm{a}$ & $100 \mathrm{a}$ & $100 \mathrm{a}$ \\
\hline 03-Atrazine+glufosinate-ammonium & Pre/Post & $93 \mathrm{c}$ & $96 \mathrm{~b}$ & $87 \mathrm{~d}$ \\
\hline 04-[Atrazine + simazine $]+$ glufosinate-ammonium & Pre/Post & $94 \mathrm{c}$ & $94 \mathrm{~b}$ & $87 \mathrm{~d}$ \\
\hline 05 -[Atrazine + oil $]+$ glufosinate-ammonium & Pre/Post & $96 \mathrm{~b}$ & $96 \mathrm{~b}$ & $88 \mathrm{~d}$ \\
\hline 06-S-metolachlor+glufosinate-ammonium & Pre/Post & $95 \mathrm{c}$ & $95 \mathrm{~b}$ & $93 \mathrm{c}$ \\
\hline 07-[Atrazine+S-metolachlor]+glufosinate-ammonium & Pre/Post & $96 \mathrm{~b}$ & $96 \mathrm{~b}$ & $90 \mathrm{~d}$ \\
\hline 08-Glufosinate-ammonium & Post & $92 \mathrm{c}$ & $92 \mathrm{~b}$ & $90 \mathrm{~d}$ \\
\hline 09-Glufosinate-ammonium + atrazine & Post & $95 \mathrm{c}$ & $95 \mathrm{~b}$ & $95 \mathrm{~b}$ \\
\hline 10-Glufosinate-ammonium $+[$ atrazine + oil $]$ & Post & $94 \mathrm{c}$ & $94 \mathrm{~b}$ & $94 \mathrm{c}$ \\
\hline 11-Glufosinate-ammonium + S-metolachlor & Post & $89 \mathrm{c}$ & $89 \mathrm{~b}$ & $91 \mathrm{c}$ \\
\hline 12-Glufosinate-ammonium $+[$ atrazine + simazine $]$ & Post & $98 \mathrm{~b}$ & $98 \mathrm{~b}$ & $96 \mathrm{~b}$ \\
\hline 13-Glufosinate-ammonium $+[$ atrazine + S-metolachlor $]$ & Post & $98 \mathrm{~b}$ & $98 \mathrm{~b}$ & $97 \mathrm{~b}$ \\
\hline 14-Glufosinate-ammonium $+[$ nicosulfuron + mesotrione $]$ & Post & $95 \mathrm{c}$ & $95 \mathrm{~b}$ & $94 \mathrm{c}$ \\
\hline CV $(\%)$ & & 4.34 & 7.78 & 3.85 \\
\hline
\end{tabular}

${ }^{1}$ Days after treatment application. 2 Means followed by the same letters in the column do not differ among one another as per Scott-Knott test at $\mathrm{p} \leq 0.05$. 
of the other molecules used in the combination. Galon et al. (2010) observed that the application of S-metolachlor in the pre-emergence of maize provided weed control until 14 DAT. The use of this herbicide in the post-emergence does not contribute to the control of the established plant, but it is efficient in the reduction of new emergence flows. It is important to highlight that all herbicide treatments presented control levels over $80 \%$, which enables them to be regarded as good control alternatives (Oliveira et al., 2009).

In respect to the control of radish, at 7 DAT all herbicides provided efficacy above $90 \%$ (Table 4). At 14 and 21 DAT, the use of glufosinateammonium in pre-emergence, combined or not with S-metolachlor, provided the lowest control levels. The low efficacy of these treatments, when compared with the others, may be related to the lack of residual effect of the glufosinateammonium and to the short residual effect of the S-metolachlor, with new weed emergence flows in the area. The other treatments presented control efficiency equivalent or superior to $90 \%$ at 21 DAT.

In the South Region of Brazil, the producers' complaints have increased in regard to radish control failures identified in wheat crops, with the use of ALS-inhibiting metsulfuron-methyl (Costa \& Rizzardi, 2013). In addition to that, this species is adapting and infesting summer crops

Table 4. Control (\%) of radish - Raphanus sativus L., infesting the maize hybrid (Forseed 2A521PW) crop, as a function of applications of herbicides combined with glufosinate-ammonium. UFFS, Erechim, RS, 2018/19.

\begin{tabular}{lcccc}
\hline \multirow{2}{*}{ Treatments } & \multirow{2}{*}{$\begin{array}{c}\text { Type of } \\
\text { application }\end{array}$} & \multicolumn{3}{c}{ Control of radish (\%) } \\
\cline { 2 - 5 } & --- & $0 \mathrm{c} T^{1}$ & $14 \mathrm{DAT}$ & $21 \mathrm{DAT}$ \\
\hline 01-Weed-infested control area & -- & $100 \mathrm{a}$ & $100 \mathrm{a}$ & $100 \mathrm{a}$ \\
02-Weed-free control area & Pre/Post & $99 \mathrm{a}$ & $99 \mathrm{a}$ & $96 \mathrm{a}$ \\
03-Atrazine+glufosinate-ammonium & Pre/Post & $99 \mathrm{a}$ & $97 \mathrm{a}$ & $91 \mathrm{~b}$ \\
04-[Atrazine+simazine]+glufosinate-ammonium & Pre/Post & $99 \mathrm{a}$ & $97 \mathrm{a}$ & $90 \mathrm{~b}$ \\
05-[Atrazine+oil]+glufosinate-ammonium & Pre/Post & $92 \mathrm{~b}$ & $91 \mathrm{~b}$ & $82 \mathrm{c}$ \\
06-S-metolachlor+glufosinate-ammonium & Pre/Post & $96 \mathrm{a}$ & $93 \mathrm{~b}$ & $97 \mathrm{a}$ \\
07-[Atrazine+S-metolachlor]+glufosinate-ammonium & Post & $94 \mathrm{~b}$ & $82 \mathrm{~b}$ & $78 \mathrm{c}$ \\
08-Glufosinate-ammonium & Post & $100 \mathrm{a}$ & $100 \mathrm{a}$ & $100 \mathrm{a}$ \\
09-Glufosinate-ammonium +atrazine & Post & $99 \mathrm{a}$ & $100 \mathrm{a}$ & $99 \mathrm{a}$ \\
10-Glufosinate-ammonium +[atrazine+oil] & Post & $91 \mathrm{~b}$ & $96 \mathrm{~b}$ & $95 \mathrm{~b}$ \\
11-Glufosinate-ammonium +S-metolachlor & Post & $100 \mathrm{a}$ & $100 \mathrm{a}$ & $100 \mathrm{a}$ \\
12-Glufosinate-ammonium +[atrazine+simazine] & Post & $100 \mathrm{a}$ & $100 \mathrm{a}$ & $100 \mathrm{a}$ \\
13-Glufosinate-ammonium +[atrazine+S-metolachlor] & Post & $99 \mathrm{a}$ & $95 \mathrm{a}$ & $99 \mathrm{a}$ \\
14-Glufosinate-ammonium +[nicosulfuron+mesotrione] & & 3.65 & 6.57 & 7.82 \\
\hline CV (\%) & & &
\end{tabular}

${ }^{1}$ Days after treatment application. ${ }^{2}$ Means followed by the same letters in the column do not differ among one another as per Scott-Knott test at $\mathrm{p} \leq 0.05$. 
like soybean, maize, beans, among others, in that same region. Therefore, due to the high efficacy of the treatments, LL maize grown in succession to wheat may represent and interesting alternative to reduce this weed's seed bank in the areas where this cereal grain is cultivated.

As to the sunflower, all treatments presented control levels above 90\%, regardless of the assessment periods (Table 5). The control of weed and volunteer plants (rogue), which grow from harvest losses, is of great importance in order to allow the crop of economic interest to express all its yield potential. Weeds and rogues, besides competing for the resources in the environment, may be hosts for pests and diseases, thus favoring the loss of productivity and profitability of the crop of interest (Silva et al., 2018). Due to these characteristics, it is important to manage those plants properly.

The glufosinate-ammonium stands out as an interesting alternative for weed management. In Brazil, there is no record of species that have biotypes resistant to that molecule (Heap, 2020). However, since it is an herbicide with contact action, its efficacy is directly related to the development stage of the target plant (Chaudhari et al., 2017). This fact, associated with the lack of residual effect in the soil, causes the management programs that make use of this technology to be dependent on the application in the appropriate weed development stage and the use of residual herbicides (Jhala et al., 2017). Crops tolerant

Table 5. Control (\%) of sunflower - Helianthus annuus, infesting the maize hybrid (Forseed 2A521PW) crop, as a function of applications of herbicides combined with glufosinate-ammonium. UFFS, Erechim, RS, 2018/19.

\begin{tabular}{|c|c|c|c|c|}
\hline \multirow{2}{*}{ Treatments } & \multirow{2}{*}{$\begin{array}{c}\text { Type of } \\
\text { application }\end{array}$} & \multicolumn{3}{|c|}{ Control of sunflower $(\%)$} \\
\hline & & $7 \mathrm{DAT}^{1}$ & 14 DAT & $21 \mathrm{DAT}$ \\
\hline 01-Weed-infested control area & --- & $0 \mathrm{c}^{2}$ & $0 \mathrm{c}$ & $0 \mathrm{~b}$ \\
\hline 02-Weed-free control area & --- & $100 \mathrm{a}$ & $100 \mathrm{a}$ & $100 \mathrm{a}$ \\
\hline 03-Atrazine+glufosinate-ammonium & Pre/Post & $100 \mathrm{a}$ & $100 \mathrm{a}$ & $99 \mathrm{a}$ \\
\hline 04-[Atrazine + simazine $]+$ glufosinate-ammonium & Pre/Post & $96 \mathrm{~b}$ & $100 \mathrm{a}$ & $94 \mathrm{~b}$ \\
\hline 05-[Atrazine+oil] + glufosinate-ammonium & Pre/Post & 99 a & $100 \mathrm{a}$ & $95 \mathrm{~b}$ \\
\hline 06-S-metolachlor+glufosinate-ammonium & Pre/Post & $96 \mathrm{~b}$ & $99 \mathrm{~b}$ & $97 \mathrm{~b}$ \\
\hline 07-[Atrazine + S-metolachlor $]+$ glufosinate-ammonium & Pre/Post & $99 \mathrm{a}$ & $100 \mathrm{a}$ & $97 \mathrm{~b}$ \\
\hline 08-Glufosinate-ammonium & Post & $94 \mathrm{~b}$ & $100 \mathrm{a}$ & $98 \mathrm{a}$ \\
\hline 09-Glufosinate-ammonium +atrazine & Post & 99 a & $100 \mathrm{a}$ & $100 \mathrm{a}$ \\
\hline 10-Glufosinate-ammonium $+[$ atrazine + oil $]$ & Post & $100 \mathrm{a}$ & $100 \mathrm{a}$ & $100 \mathrm{a}$ \\
\hline 11-Glufosinate-ammonium + S-metolachlor & Post & $100 \mathrm{a}$ & $100 \mathrm{a}$ & $98 \mathrm{a}$ \\
\hline 12-Glufosinate-ammonium +[atrazine+simazine $]$ & Post & 99 a & $100 \mathrm{a}$ & $100 \mathrm{a}$ \\
\hline 13-Glufosinate-ammonium +[atrazine+S-metolachlor $]$ & Post & $100 \mathrm{a}$ & $100 \mathrm{a}$ & $100 \mathrm{a}$ \\
\hline 14-Glufosinate-ammonium + [nicosulfuron + mesotrione $]$ & Post & $100 \mathrm{a}$ & $100 \mathrm{a}$ & $97 \mathrm{~b}$ \\
\hline $\mathrm{CV}(\%)$ & & 2.13 & 0.33 & 2.67 \\
\hline
\end{tabular}

${ }^{1}$ Days after treatment application. ${ }^{2}$ Means followed by the same letters in the column do not differ among one another as per Scott-Knott test at $\mathrm{p} \leq 0.05$. 
to glufosinate-ammonium have been used as an important alternative to help with the management of biotypes resistant to glyphosate (Ganie \& Jhala, 2017) and, consequently, allow the possibility of alternating different mechanisms of action in crops.

The herbicide treatments did not affect yield components or grain production of the crop (Table 6). This fact can be attributed to the low phytotoxicity levels and high efficacy in weed control. When comparing the average value of the herbicide treatments with the weed-infested control, there is an increment of 57\% in grain yield. Silva et al. (2017), when assessing the selectivity of glyphosate and glufosinateammonium, applied alone or in association with atrazine in maize (RR/LL), observed

Table 6. Ear insertion height (EIH - m), number of rows per ear (NRE), number of grains per row (NGR), thousand grain weight (TGW - g) and grain yield (GY - $\mathrm{kg} \mathrm{ha}^{-1}$ ) for the Forseed 2A521PW maize hybrid, as a function of applications of herbicides associated with glufosinate-ammonium. UFFS, Erechim, RS, 2018/19.

\begin{tabular}{|c|c|c|c|c|c|c|}
\hline \multirow{2}{*}{ Treatments } & \multirow{2}{*}{$\begin{array}{c}\text { Type of } \\
\text { application }\end{array}$} & \multicolumn{5}{|c|}{ Yield components of maize } \\
\hline & & EIH & NRE & NGR & TGW & GY \\
\hline 01-Weed-infested control area & --- & $1.04^{\mathrm{ns}}$ & $13.40 \mathrm{~b}$ & $25^{\text {ns }}$ & $360.04^{\mathrm{ns}}$ & $3262.40 \mathrm{~b}$ \\
\hline 02-Weed-free control area & --- & 0.97 & $14.70 \mathrm{a}$ & 31 & 428.41 & $5220.19 \mathrm{a}$ \\
\hline 03-Atrazine+glufosinate-ammonium & Pre/Post & 1.03 & $14.30 \mathrm{a}$ & 26 & 436.66 & $5203.03 \mathrm{a}$ \\
\hline 04-[Atrazine+simazine]+glufosinate-ammonium & Pre/Post & 0.96 & $14.80 \mathrm{a}$ & 29 & 400.03 & $4630.40 \mathrm{a}$ \\
\hline 05-[Atrazine + oil $]+$ glufosinate-ammonium & Pre/Post & 1.00 & $13.70 \mathrm{~b}$ & 29 & 424.51 & $4790.84 \mathrm{a}$ \\
\hline 06-S-metolachlor+glufosinate-ammonium & Pre/Post & 1.05 & $14.60 \mathrm{a}$ & 29 & 407.16 & $4840.99 \mathrm{a}$ \\
\hline 07-[Atrazine+S-metolachlor]+glufosinate-ammonium & Pre/Post & 1.01 & $14.70 \mathrm{a}$ & 28 & 379.56 & $4932.18 \mathrm{a}$ \\
\hline 08-Glufosinate-ammonium & Post & 0.99 & $14.90 \mathrm{a}$ & 27 & 392.11 & 4399.69 a \\
\hline 09-Glufosinate-ammonium + atrazine & Post & 1.00 & $14.70 \mathrm{a}$ & 30 & 385.03 & $5633.61 \mathrm{a}$ \\
\hline 10-Glufosinate-ammonium $+[$ atrazine + oil $]$ & Post & 1.01 & $14.70 \mathrm{a}$ & 28 & 393.03 & $4904.12 \mathrm{a}$ \\
\hline 11-Glufosinate-ammonium + S-metolachlor & Post & 1.01 & $14.70 \mathrm{a}$ & 28 & 402.51 & $4674.88 \mathrm{a}$ \\
\hline 12-Glufosinate-ammonium $+[$ atrazine + simazine $]$ & Post & 1.05 & $14.40 \mathrm{a}$ & 29 & 383.63 & $5359.64 \mathrm{a}$ \\
\hline 13-Glufosinate-ammonium+[atrazine+S-metolachlor] & Post & 1.03 & $14.20 \mathrm{a}$ & 28 & 399.08 & $5170.82 \mathrm{a}$ \\
\hline 14-Glufosinate-ammonium + [nicosulfuron + mesotrione $]$ & Post & 0.94 & $14.40 \mathrm{a}$ & 29 & 403.14 & $4654.83 \mathrm{a}$ \\
\hline CV (\%) & & 6.00 & 4.36 & 7.02 & 6.75 & 12.80 \\
\hline
\end{tabular}

${ }^{\mathrm{ns}}$ Not significant at $\mathrm{p} \leq 0.05 .{ }^{1}$ Means followed by the same letters in the column do not differ among one another as per Scott-Knott test at $\mathrm{p} \leq 0.05$. 
that the use of these molecules did not result in losses regarding yield components or crop productivity. The results corroborate those found by Gemelli et al. (2013) who verified no yield losses with application of atrazine combined with glufosinate-ammonium. Lack of visual damages or negative impacts on productivity are relevant traits for the acceptance and diffusion of the technology among rural producers.

The use of glufosinate-ammonium associated with other herbicide molecules was selective and efficient for weed control in LL maize crop. Rotation of active ingredients and combination of herbicides with different mechanisms of action are important practices for the management of weed resistance to herbicides. In this scenario, the LL maize enables the use of a new active ingredient in the post-emergence of the crop, which promotes the increase of alternatives for weed control.

\section{Conclusion}

The herbicides applied in association with glufosinate-ammonium were efficient in the control of alexandergrass, radish and sunflower, and were selective to the Forseed 2A521 PW maize hybrid (RR/LL). The maize grain yield components were not negatively impacted by the application of glufosinate-ammonium associated with the other herbicides. The weed control presents increment of $57 \%$ in maize grain yield.

\section{Acknowledgments}

To CNPq, FAPERGS, UFFS and FINEp for the provision of financial support to the research and for the scholarships granted.

\section{References}

ACOMPANHAMENTO DA SAFRA BRASILEIRA [DE] GRÃOS: safra 2019/20: quinto levantamento. Brasília, DF: Conab, v. 7, n. 5 , fev. 2020 .

ADEGAS, F. S.; VARGAS, L.; GAZZIERO, D. L. P.; KARAM, D.; SILVA, A. F. da; AGOSTINETTO, D. Impacto econômico da resistência de plantas daninhas a herbicidas no Brasil. Londrina: Embrapa Soja, 2017. 11 p. (Embrapa Soja. Circular Técnica, 132).

ARMEL, G. R.; RICHARDSON, R. J.; WILSON, H. P.; HINES, T. E. Mesotrione and glufosinate in glufosinate-resistant corn. Weed Technology, v. 22, n. 4, p. 591-596, 2008. DOI: 10.1614/WT08-048.1.

BRASIL. Ministério da Agricultura, Pecuária e Abastecimento. AGROFIT: sistema de agrotóxicos fitossanitários. Brasília, DF, c2003. Disponível em: <http://agrofit.agricultura.gov. br/agrofit_cons/principal_agrofit_cons $>$. Acesso em: 15 abr. 2020.

BURKE, I. C.; THOMAS, W. E.; ALLEN, J. E.; 
COLLINS, J.; WILCUT, J. W. A comparison of weed control in herbicide-resistant, herbicidetolerant, and conventional corn. Weed Technology, v. 22, n. 4, p. 571-579, 2008. DOI: 10.1614/WT-07-184.1.

COMISSÃO TÉCNICA NACIONAL DE BIOSSEGURANÇA - CTNBio. Disponível em: $<$ http://ctnbio.mctic.gov.br/inicio $>$. Acesso em: 20 abr. 2020.

COSTA, L. O.; RIZZARDI, M. A. Herbicidas alternativos para o controle de Raphanus raphanistrum L. resistente ao herbicida metsulfurom metílico. Revista Brasileira de Herbicidas, v. 12, n. 3, p. 268-276, 2013. DOI: 10.7824/rbh.v12i3.240.

CHAUDHARY,V.P.; SINGH,K.K.;PRATIBHA, G.; BHATTACHARYYA, R.; SHAMIM, M.; PATEL, A. Energy conservation and greenhouse gas mitigation under different production systems in rice cultivation. Energy, v. 130, p. 307-317, 2017. DOI: 10.1016/j.energy.2017.04.131.

GALON, L.; TIRONI, S. P.; FERREIRA, E. A.; ASPIAZÚ, I.; PINTO, J. J. O. Avaliação do método químico de controle de papuã (Brachiaria plantaginea) sobre a produtividade do milho. Pesquisa Agropecuária Tropical, v. 40, n. 4, p. 414-421, 2010. DOI: 10.1590/S198340632010000400019 .

GALON, L.; DAVID, F. A.; FORTE, C. 2017. DOI: DOI: 10.1017/wet.2016.8.
T.; REICHERT JR., F. W.; RADUNZ, A. L.; KUJAWINSKI, R.; RADUNZ, L. L.; CASTOLDI, C. T.; PERIN, G. F.; MOSSI, A. J. Chemical management of weeds in corn hybrids. Weed Biology and Management, v. 18, n. 1, p. 26-40, 2018. DOI: 10.1111/wbm.12141.

GANIE, Z. A.; JHALA, A. Glyphosate-resistant common ragweed (Ambrosia artemisiifolia) in Nebraska: confirmation and response to postemergence corn and soybean herbicides. Weed Technology, v. 31, n. 2, p. 225-237, 2017. DOI: 10.1017/wet.2016.26.

GEMELLI, A.; OLIVEIRA JR., R. S.; CONSTANTIN, J.; RAZ, G. B. P.; JUMES, T. M. C.; GHENO, E. A.; RIOS, F. A.; FRANCHINI, L. H. M. Estratégias para o controle de capimamargoso (Digitaria insularis) resistente ao glyphosate na cultura milho safrinha. Revista Brasileira de Herbicidas, v. 12, n. 2, p. 162170, 2013. DOI: 10.7824/rbh.v12i2.201.

HEAP, I. International survey of herbicide resistant weeds. Disponível em: $<$ http://www. weedscience.org/Summary/Country.aspx?> . Acesso em: 23 mar. 2020.

JHALA, A. J.; SANDELL, L. D.; SARANGI, D.; KRUGER, G. R.; KNEZEVIC, S. Z. Control of glyphosate-resistant common waterhemp (Amaranthus rudis) in glufosinate-resistant soybean. Weed Technology, v. 31, n. 1, p. 32-45, 
LATORRE, D.; SILVA, I. P. F.; JUNIOR, J. F. S.; PUTTI, F. F.; SCHIMIDT, A. P.; LUDWIG, R. Herbicidas inibidores da glutamina sintetase.

\section{Revista Brasileira de Engenharia de}

Biossistemas, v. 7, n. 3, p. 134-141, 2013. DOI: 10.18011/bioeng2013v7n3p134-141.

LUCIO, F. R.; KALSING, A.; ADEGAS, F. S.; VITAGLIANO, S. R.; CORREIA, N. M.; GAZZIERO, D. L. P.; SILVA, A. F. Dispersal and frequency of glyphosate-resistant and glyphosate-tolerant weeds in soybean-producing edaphoclimatic microregions in Brazil. Weed Technology, v. 33, n. 1, p. 217-231, 2019. DOI: 10.1017/wet.2018.97.

MANUAL de adubação e calagem para os estados do Rio Grande do Sul e Santa Catarina. 10. ed. Porto Alegre: Sociedade Brasileira de Ciência do Solo, 2016. 376 p.

OLIVEIRA, A. R.; FREITAS, S. P.; VIEIRA, H. D. Controle de Commelina benghalensis, C. erecta, Tripogandra diuretica na cultura do café. Planta Daninha, v. 27, n. 4, p. 823-830, 2009. DOI: $10.1590 / \mathrm{S} 0100-83582009000400021$.

RODRIGUES, B. N.; ALMEIDA, F. R. Guia de herbicidas. 7. ed. Londrina: Edição dos Autores, 2018. $764 \mathrm{p}$.

SANTOS, H. G. dos; JACOMINE, P. K. T.;ANJOS, L. H. C. dos; OLIVEIRA, V. A. de; LUMBRERAS, J. F.; COELHO, M. R.; ALMEIDA, J. A. de;
CUNHA, T. J. F.; OLIVEIRA, J. B. de. Sistema brasileiro de classificação de solos. 3. ed. rev. e ampl. Brasília, DF: Embrapa, 2013. 353 p.

SILVA, A. F.; ADEGAS, F. S.; CONCENÇO, G. Characterization of emergence flows of volunteer corn as function of the type of harvest grain loss. Journal of Agricultural Science, v. 10, n. 5, p. 258-267, 2018. DOI: 10.5539/jas. v10n5p258.

SILVA, A. F. M.; SILVA, A. F. M.; ALBRECHT, A. J. P.; GIOVANELLI, B. F.; GHIRATDELLO, G. A.; DAMiÃO, V. W.; ALBRECHT, L. P.; VICTORIA FILHO, R. Seletividade de herbicidas isolados e em associações para milho RR2/LL. Revista Brasileira de Herbicidas, v. 16 , n. 1 , p. $60-66,2017$. DOI: $10.7824 /$ rbh. v16i1.509.

TIMOSSI, P. C.; FREITAS, T. T. Eficácia de nicosulfuron isolado e associado com atrazine no manejo de plantas daninhas em milho. Revista Brasileira de Herbicidas, v. 10, n. 3, p. 210-218, 2011. DOI: 10.7824/rbh.v10i3.123. VELINI, E. D.; OSIPE, R.; GAZZIERO, D. L. P. (Coord.). Procedimentos para instalação, avaliação e análise de experimentos com herbicidas. Londrina: SBCPD, 1995. 42 p.

WANDSCHEER, A. C. D.; RIZZARDI, M. A.; REICHERT, M.; GAVIRAGHI, F. Capacidade competitiva da cultura do milho em relação 
ao capim-sudão. Revista Brasileira de Milho WESTWOOD, J. H.; CHARUDATTAN, R.; e Sorgo, v. 13, n. 2, p. 129-141, 2014. DOI: DUKE, S. O.; FENNIMORE, S. A.; MARRONE, 10.18512/1980-6477/rbms.v13n2p129-141. P.; SLAUGHTER, D. C.; SWANTON, C.; ZOLLINGER, R. Weed management in 2050: perspectives on the future of weed science. Weed Science, v. 66, n. 3, p. 275-285, 2018. DOI: 10.1017/wsc.2017.78. 
Revista Brasileira de Milho e Sorgo, v.19, e1194, 2020

DOI: https://doi.org/10.18512/rbms2020v19e1194 
